DOI: https://doi.org/10.24127/ajpm.v10i4.3889

\title{
TEACHERS' CHALLENGES IN TEACHING GEOMETRY USING AUGMENTED REALITY LEARNING MEDIA
}

\author{
Gabriella Intan Permatasari $^{{ }^{*}}$, Sri Andayani \\ ${ }^{1 *}$, Universitas Negeri Yogyakarta, Yogyakarta, Indonesia \\ *Corresponding author. \\ E-mail: Gabriellaintan.2019@student.uny.ac.id ${ }^{\left.{ }^{*}\right)}$ \\ Andayani@uny.ac.id ${ }^{2}$
}

Received 30 June 2021; Received in revised form 13 September 2021; Accepted 15 December 2021

\begin{abstract}
Geometry is important for students' mastery of mathematics. In its application, students are still constrained in imagining an abstract object. It takes an appropriate learning media that is used by teachers and follows current technological developments. This study aims to describe challenges in teaching geometry using Augmented Reality learning media. This research is a qualitative research with a type of phenomenology. Data were collected by interviewing 10 junior high school mathematics teachers in Salatiga who have used Augmented Reality media in learning geometry by face to face and 12 students by zoom. Data analysis was performed using the Miles \& Huberman stage, namely data reduction, data presentation, and drawing conclusion. The results showed that the teachers still had difficulty in monitoring students whether they correctly understood the material or not during learning process in the online classes because some students didn't have smartphones that support the learning process, the limited time that the teachers had to explain the material, the display of the AR application on the smartphone can't directly scan the marker so it takes time to display the solid figure, teachers have difficulty dealing with students were less active in exploring solid figure in media so when teacher asked to describe the net of polyhedron some students only described the same shapes as those shown on AR media, and navigation in applications is too sensitive makes students confused when rotating shapes.
\end{abstract}

Keywords: Augmented reality; geometry; learning media.

\begin{abstract}
Abstrak
Geometri berperan penting terhadap penguasaan matematika siswa. Dalam penerapannya, siswa masih terkendala dalam membayangkan suatu objek abstrak. Dibutuhkan suatu media pembelajaran yang tepat yang digunakan oleh guru dan mengikuti perkembangan teknologi saat ini. Penelitian ini bertujuan untuk mendeskripsikan tantangan dalam mengajarkan geometri menggunakan media pembelajaran Augmented Reality. Penelitian ini merupakan merupakan penelitian kualitatif dengan jenis phenomenology. Data dikumpulkan dengan wawancara dengan 10 guru matematika SMP di Kota Salatiga yang telah menggunakan media Augmented Reality dalam pembelajaran Geometri secara tatap muka dan 12 siswa melalui zoom. Analisis data dilakukan dengan menggunakan tahap Miles \& Huberman, yaitu reduksi data, penyajian data, dan penarikan kesimpulan. Hasil penelitian menunjukkan bahwa guru masih kesulitan dalam memantau siswa apakah siswa benar paham materi atau tidak karena beberapa siswa tidak memiliki smartphone yang mendukung pembelajaran, kurangnya waktu yang dibutuhkan oleh guru dalam menjelaskan materi, tampilan aplikasi AR pada smartphone tidak bisa langsung scan marker sehingga butuh waktu untuk menampilkan gambar bangun ruang, guru kesulitan menghadapi siswa yang kurang aktif dalam mengeksplorasi gambar pada media ketika guru meminta siswa menggambarkan jaring-jaring bangun ruang sisi datar, dan navigasi pada aplikasi terlalu sensitive sehingga siswa kebingungan saat diminta memutar bangun ruang pada media.
\end{abstract}

Kata kunci: Augmented reality; geometri; media pembelajaran.

Thisis an open access article under the Creative Commons Attribution 4.0 International License 
DOI: https://doi.org/10.24127/ajpm.v10i4.3889

\section{INTRODUCTION}

Mathematics is a subject that is studied by students at every level of education. (NCTM, 2000; Syahputra, 2013) determines 5 content standards in mathematical standards, namely numbers and their operations, problem solving, geometry and measurement, as well as probability and data analysis. One of the materials that is important for students to learn is geometry. Geometry is one of the aspects of mathematics that deals with a plane or space. The objectives of learning geometry are to develop logical thinking skills, develop spatial intuition about the real world, impart the knowledge needed for advanced mathematics and are also expected to teach how to read and interpret mathematical arguments (Purborini \& Hastari, 2019). Basically, geometry lessons have been taught to students since they entered elementary school. The elements in geometry are the use of visualization, spatial reasoning and modeling so that the material given to students is adjusted to the students' level of thinking at each level. To achieve the geometry competency requirements, geometry material is included in the mathematics curriculum starting from elementary school to college. In this regard, to study geometry the students are required to be able to develop their spatial abilities. This is in line with Syahputra (2013) which states that engineering and mathematics, especially geometry, requires spatial abilities.

However, in practice, there are still many students who face difficulties. Research from Siswanto (2016) shows that the lack of imagination to visualize the components of the shape of the space so that students have difficulty in constructing the shapes and solving problems. Other than that,Nugraha \& Muhtadi (2015) also stated that the teacher in delivering the material of polyhedron is still using lecture method although sometimes they carry props in the form of a block or cube model frame, the teacher does not ask students to point directly at the model on the sides, edges, corner points, diagonals plane, diagonal space or diagonal plane. The research from Awwalin (2021) finding that some students are less able to solve problems of area, volume of cuboid and prisms because they don't understand the question properly and thelack of students' interest in solving problems. Based on this, it is necessary to have an appropriate learning media and make students to be more interactive. One of the learning media that can be used is technology-based learning media.

Learning media is a component as an intermediary that carries messages or information for instructional purposes or contains teaching intentions between the source and recipient (Arsyad, 2016). Other than that, (Gagne et al., 2020; Adam \& TS, 2015) also states that learning media are all physical tools that can present messages and stimulate students to learn. Arsyad (2016) classifies media into two broad categories, namely 1) traditional media choices consisting of: projected silent visuals, non-projected visuals, audio, multimedia presentations, projected dynamic visuals, print, games and reality, and 2) choice of cutting-edge technology media consisting of telecommunication-based media and microprocessor-based media. Learning media is needed as an intermediary for teachers to convey material in the form of abstract so that it's easier for students to understand because students are easier to understand learning material if 
students can imagine it (Zuin, Rigatelli, Faggian, \& Roncon, 2018). With regard to technology, (NCTM, 2000; Syahputra, 2013) states that technology influence the mathematics that is taught and enhances students' learning. From this statement, it shows that technologybased learning media has an influence in learning mathematics.

The use of technology-based learning media in the learning process is a demand for 21st century learning (Hadijah, 2018). Learning in this century is characterized by the development of digital information (Syahputra, 2018). Students have to seek information from multiple sources and sort information analytically and critically. Not only students, teachers also have to improve the quality of teaching by upgrading teacher professionalism and learning resources. This becomes a challenge for students in understanding the material and teachers in conveying the material well and clearly. For teachers, there are two challenges that must be faced in this century's learning. The first challenge comes from a change in perceptions about learning itself and the second challenge comes from the existence of information and telecommunications technology which shows extraordinary developments (Hadijah, 2018). The presence of technology-based learning media can help teachers to deliver their teaching materials and providing added value in learning activities. This applies to all types of media, both sophisticated and expensive, or simple and inexpensive learning media (Hadijah, 2018). One of the technology-based learning media that can be used is Augmented Reality.

Augmented Reality (AR) is a new technology that blurs the line between what's real and what is computer generated by enhancing what we see, smell, hear and feel. It is said to change the way we see the world around us. It basically adds a layer of graphics and other sensory enhancements on the natural world as it exists in real time (Agrawal, Kulkarni, A.Josh, \& Tiku, 2015). Furthermore, Azuma; Pangestu \& Setyaningrum (2020) states that AR is the process of combining virtual objects into the real world that are interactive in real time with 3D animation. This is in line with Abas \& Badioze Zaman (2010) arguing that AR involves interaction, virtual content, real environments, storytelling and digital imagination. Regarding the projection of three-dimensional virtual objects, AR has a positive impact on students' spatial abilities. Research from Lee (2012) stated that the role of technological developments in the virtual field in the form of augmented reality can help students to understand the material. The process of understanding emerges through the presentation of real and interesting 3D drawing material to students. So, students find it easy to understand pictures, they are motivated and entertained, it can also attract students' attention in learning. In addition, research from Pangestu (2020) also stated that AR-based learning improves the spatial reasoning abilities of junior high school students. AR provides the opportunity for students to explore geometric objects in three dimensions and from different angles.

Based on the background of the problem and the literature review above, it can be understood that students' mastery of geometry depends on the right learning media. AR can be used as one of the alternative media in learning mathematics. However, the use of AR in learning mathematics is not easy for teachers in Indonesia. Therefore, this 
study aims to describe the challenges of teaching geometry using AR learning media.

\section{METHOD}

This research is a qualitative research with a type of phenomenology. The subjects of this study were 10 junior high school mathematics teachers from 6 state Junior High Schools in Salatiga City and then researcher was collected data through interview with teachers by face to face and 12 students by zoom. The material to be discussed is polyhedron. Learning media based on Augmented Reality using the ARGeo (Augmented Reality Geometry) application on the play store. Teachers and students used smartphones with the android operating system. The phenomenon raised in this study is teachers' challenges in teaching geometry using Augmented Reality learning media. Data analysis used Miles and Huberman stages with 3 stages, namely data reduction, data presentation, and drawing conclusions. Broadly speaking, the analysis used is to record all problems or phenomena that occur in the field obtained through the results of previous interviews, Furthermore, the results of the interview will be reviewed and separate data that are considered to have the same statement, describe the classified data by paying attention to the focus of this research and finally make the final analysis in the form of a conclusion to the problem.

The interview aspect of this research based on Rabbi \& Ullah (2013) include: (1) performance challenges which concerned with real time processing, responding and evolving with the change of real world environment and (2) interaction challenges refer to the interaction of users with virtual and real objects at the same time. Interaction uses various interfaces that may be acoustic, haptic, tangible, gaze, or text based through which the user interacts with virtual objects.

Teachers who participated in this study were willing to be interviewed voluntarily and without coercion. All data submitted to the researcher through interviews were only used for this study. All identities and matters related to participants' answers are kept confidential and don't affect the future fate of participants.

\section{RESULT AND DISCUSSION}

\section{Teachers' challenges in teaching geometry to students}

Based on the results of interviews with the teachers, geometry material is difficult to teach students because it requires high imaginative abilities to understand spatial shapes. The sub material being taught is to build a flat side room. This can be seen from the teacher's and students' responses regarding geometry material. The data are presented in Table 1 and Table 2.

Table 1. Student responses related to geometry material

\begin{tabular}{|c|c|}
\hline Data reduction & Conclusion \\
\hline $\begin{array}{l}\text { - Yes, mam } \\
\text { - Yes, it's quite difficult, } \\
\text { sometimes it is } \\
\text { difficult, sometimes } \\
\text { it's easy } \\
\text { - Yes, because it's kind } \\
\text { of hard to imagine the } \\
\text { polyhedron. } \\
\text { - If the material about } \\
\text { the elements is easy } \\
\text { but if it has been } \\
\text { calculated difficult } \\
\text { - yes, that part of the } \\
\text { nets is hard for him. } \\
\text { - Yes, because the shape } \\
\text { is 2D so can't see } \\
\text { directly if inside the } \\
\text { cube what it looks like }\end{array}$ & $\begin{array}{l}\text { Students find it } \\
\text { difficult to learn } \\
\text { geometry } \\
\text { polyhedron sub } \\
\text { material because } \\
\text { students still have } \\
\text { difficulty imagining } \\
\text { solid figure, } \\
\text { depicting the nets } \\
\text { of solid figure, and } \\
\text { during their } \\
\text { learning are given } \\
\text { 2D-shaped images. }\end{array}$ \\
\hline
\end{tabular}


DOI: https://doi.org/10.24127/ajpm.v10i4.3889

Table 2. Teacher responses related to geometry material

\begin{tabular}{|c|c|}
\hline Data reduction & \\
\hline $\begin{array}{l}\text { Yes, I think so } \\
\text { Yes, it's quite difficult } \\
\text { Yes, sometimes it is } \\
\text { difficult, sometimes it's } \\
\text { not } \\
\text { Yes, because children are } \\
\text { still confused to determine } \\
\text { the difference between the } \\
\text { face diagonal and diagonal } \\
\text { plane } \\
\text { Yes, because they still } \\
\text { have difficulty to imagine } \\
\text { the net of polyhedron, } \\
\text { especially in prisms and } \\
\text { pyramids } \\
\text { It's quite difficult because } \\
\text { the children's ability to } \\
\text { imagine are different, } \\
\text { some can immediately } \\
\text { understand, some have to } \\
\text { be explained many times } \\
\text { I often give them quizzes } \\
\text { and homework. The } \\
\text { average results of their } \\
\text { work are the same and the } \\
\text { steps are the same, so } \\
\text { when I directly tested } \\
\text { them one by one, there } \\
\text { were those who couldn't } \\
\text { answer the } \\
\text { Yes, it can be seen from } \\
\text { the low scores in their } \\
\text { daily test } \\
\text { Judging from the daily test } \\
\text { scores, if they thought the } \\
\text { questions were a little bit } \\
\text { complicated, they would } \\
\text { definitely answer them } \\
\text { wrong. In addition, it } \\
\text { seems that they only } \\
\text { memorize and do not } \\
\text { understand it well, so the } \\
\text { results are still lacking. }\end{array}$ & $\begin{array}{l}\text { Most teachers } \\
\text { state that } \\
\text { geometry is a } \\
\text { difficult } \\
\text { material, } \\
\text { especially on } \\
\text { the material of } \\
\text { polyhedron. } \\
\text { Students still } \\
\text { have difficulty } \\
\text { to determine } \\
\text { elements of } \\
\text { solid figure } \\
\text { such as face } \\
\text { diagonal and } \\
\text { diagonal plane, } \\
\text { imagining the } \\
\text { net of } \\
\text { polyhedron } \\
\text { such as prisms } \\
\text { and pyramids. } \\
\text { This can be } \\
\text { seen from the } \\
\text { results of the } \\
\text { students daily } \\
\text { test scores } \\
\text { which are still } \\
\text { lacking and } \\
\text { students cannot } \\
\text { answer the } \\
\text { teacher's } \\
\text { questions } \\
\text { during the oral } \\
\text { test. }\end{array}$ \\
\hline
\end{tabular}

To teach geometry, there are several ways for the teacher use, especially in the sub-material of polyhedron. The data are presented in Table 3.
Table 3. Teacher's method of teaching geometry

\begin{tabular}{ll}
\hline \multicolumn{1}{c}{ Data reduction } & \multicolumn{2}{c}{ Conclusion } \\
\hline - Mostly use textbooks & Teachers use \\
or provide material by & textbooks, props, \\
YouTube to explain and YouTube media & an of more than they use \\
the material of & more \\
polyhedron & AR learning media \\
- Only use AR learning & to explain the \\
media at certain times & material \\
- Using props & polyhedron \\
\hline
\end{tabular}

The way the teacher teaches geometry uses more textbooks, props and YouTube media to teach geometry. However, in the learning process, there are challenges faced by teachers. Teachers' challenges in teaching geometry are presented in Table 4.

Table 4. Teachers' challenges in teaching geometry to students

\begin{tabular}{l}
\hline \multicolumn{2}{c}{ Conclusion } \\
\hline - The lack of time for \\
teachers to pay lack of time \\
attention to students \\
one by one so that the attention to students \\
teachers didn't know in understanding the \\
whether students material. In addition, \\
understand the the learning media \\
material or not hy the \\
- Teachers have not students so that \\
been able to facilitate interact directly with \\
learning media for all these props. \\
students so that \\
students cannot \\
interact directly with \\
these media
\end{tabular}

\section{Constrained faced by teachers using AR learning media}

Media is a component that is used as an intermediary between sources and recipients in obtaining visual or verbal knowledge or information. Following are the results of data reduction related to teacher understanding of AR learning media. The data are presented in Table 5. 
DOI: https://doi.org/10.24127/ajpm.v10i4.3889

Table 5. Teachers' understanding of AR learning media

\begin{tabular}{|c|c|}
\hline Data reduction & Conclusion \\
\hline $\begin{array}{l}\text { Learning media that helps } \\
\text { teachers in teaching the } \\
\text { material to build a } \\
\text { polyhedron } \\
\text { Helping students to be } \\
\text { able to interact directly } \\
\text { with structures that are } \\
\text { difficult for them to } \\
\text { imagine } \\
\text { A media suitable for } \\
\text { today's technology-based } \\
\text { learning } \\
\text { Media that uses markers to } \\
\text { display space }\end{array}$ & $\begin{array}{l}\text { Most of the } \\
\text { teachers stated } \\
\text { that } \\
\text { learning media } \\
\text { is a medium } \\
\text { that relps } \\
\text { teachers and } \\
\text { students in } \\
\text { learning the } \\
\text { material of } \\
\text { polyhedron }\end{array}$ \\
\hline
\end{tabular}

Interviews were conducted by 10 mathematics teacher for grade 8 junior high school in Salatiga City. The 10 teachers have used AR in learning the geometry of polyhedron with a maximum of 4 meetings for each indicator, namely cubes, blocks, prisms, and pyramids. The data on the use of AR learning media by the teacher is presented in Table 6.

Table 6. The use of AR learning media by the teacher

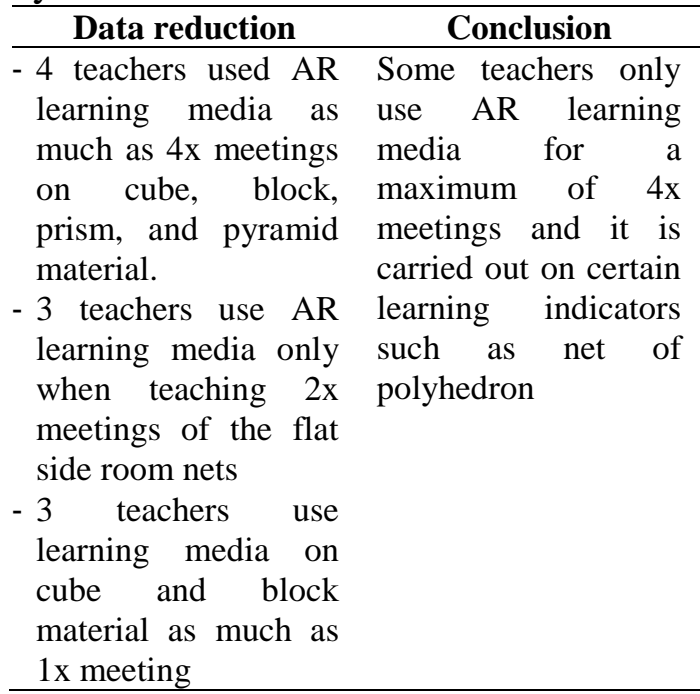

Based on the results of interviews with 10 teachers dan students who have used AR learning media, there are obstacles faced when using AR learning media. These challenges are presented in Table 7 and Table 8.

Table 7. Constrained faced by teachers using AR learning media

\begin{tabular}{|c|c|}
\hline Data reduction & Conclusion \\
\hline $\begin{array}{l}\text { - At the beginning, teachers } \\
\text { are still confused about } \\
\text { using AR media because } \\
\text { this media is new to } \\
\text { teachers } \\
\text { - When the teacher scanned } \\
\text { the marker, the image did } \\
\text { not appear immediately } \\
\text { because the lighting was too } \\
\text { bright and it took a long } \\
\text { time to show the image } \\
\text { - The camera used cannot } \\
\text { scan markers clearly, so that } \\
\text { the building space cannot be } \\
\text { projected properly. } \\
\text { - Lack of complete } \\
\text { information on AR media so } \\
\text { that the teacher is confused } \\
\text { about which part is for the } \\
\text { material and which part is } \\
\text { for question practice } \\
\text { - In face-to-face learning, } \\
\text { students are not allowed to } \\
\text { use smartphones in class so } \\
\text { they only use the teacher's } \\
\text { smartphone and show it to } \\
\text { students }\end{array}$ & $\begin{array}{l}\text { Lack of } \\
\text { complete } \\
\text { information } \\
\text { so that } \\
\text { teachers are } \\
\text { still confused } \\
\text { in using AR } \\
\text { learning } \\
\text { media } \\
\text { The camera } \\
\text { used cannot } \\
\text { scan markers } \\
\text { clearly so that } \\
\text { the teacher } \\
\text { cannot } \\
\text { immediately } \\
\text { display the } \\
\text { projections of } \\
\text { the building } \\
\text { space properly }\end{array}$ \\
\hline
\end{tabular}

Table 8. Constrained faced by students using AR learning media

\begin{tabular}{|c|c|}
\hline Data reduction & \\
\hline $\begin{array}{l}\text { Smartphones that do } \\
\text { not support so } \\
\text { students can not } \\
\text { directly scan markers }\end{array}$ & $\begin{array}{l}\text { - Smartphones that } \\
\text { do not support } \\
\text { result in students } \\
\text { less interacting } \\
\text { with the media }\end{array}$ \\
\hline $\begin{array}{l}\text { When scanning } \\
\text { markers, images do } \\
\text { not appear directly } \\
\text { due to overexposure }\end{array}$ & $\begin{array}{l}\text { - The camera used is } \\
\text { less clear so that } \\
\text { the room can't be } \\
\text { projected properly }\end{array}$ \\
\hline $\begin{array}{l}\text { The camera used } \\
\text { can't scan the marker } \\
\text { clearly, so the solid } \\
\text { figure can't be } \\
\text { projected properly }\end{array}$ & $\begin{array}{l}\text { - Navigation buttons } \\
\text { on overly sensitive } \\
\text { media because } \\
\text { students confusion } \\
\text { when rotating the } \\
\text { solid figure }\end{array}$ \\
\hline
\end{tabular}


DOI: https://doi.org/10.24127/ajpm.v10i4.3889

\begin{tabular}{lll}
\hline \multicolumn{2}{c}{ Data reduction } & \multicolumn{1}{c}{ Conclusion } \\
\hline - Navigation buttons on & - Lack & of \\
media that are too & information on the \\
sensitive so that when & use of media for \\
rotating the solid & materials & and \\
figure becomes too exercises & \\
fast & \\
- Lack of information & \\
on the use of media & \\
for materials and \\
exercises
\end{tabular}

\section{Teachers' challenges in teaching geometry using AR learning media}

There are challenges faced by teachers in teaching geometry with AR learning media, especially in the material of polyhedron. The data are presented in Table 9.

Table 9. Teachers' challenges in teaching geometry with AR learning media

\begin{tabular}{|c|c|}
\hline Data reduction & Conclusion \\
\hline $\begin{array}{l}\text { - The display of the AR } \\
\text { application on the } \\
\text { smartphone can't } \\
\text { directly scan the marker } \\
\text { so it takes time to } \\
\text { display the solid figure. } \\
\text { - In online study, the } \\
\text { internet signal is not } \\
\text { good so that teachers } \\
\text { cannot monitor students } \\
\text { during study } \\
\text { - In online study, teachers } \\
\text { still have difficulty } \\
\text { when observing students } \\
\text { whether students really } \\
\text { understand the material } \\
\text { or just following } \\
\text { instructions from the } \\
\text { teacher. } \\
\text { - Some students are less } \\
\text { active in using the } \\
\text { media so they only see } \\
\text { pictures but they didn't } \\
\text { explore } \\
\text { - When asked to describe } \\
\text { the net of polyhedron, } \\
\text { some students only } \\
\text { described the same } \\
\text { shapes as those shown } \\
\text { on AR media } \\
\text { - When students are asked }\end{array}$ & $\begin{array}{l}\text { - The teachers still } \\
\text { had difficulty in } \\
\text { monitoring } \\
\text { students whether } \\
\text { they correctly } \\
\text { understood the } \\
\text { material or not } \\
\text { during learning } \\
\text { process in the } \\
\text { online classes } \\
\text { because some } \\
\text { students didn't } \\
\text { have smartphones } \\
\text { that support the } \\
\text { learning process. } \\
\text { - The limited time } \\
\text { that the teachers } \\
\text { had to explain the } \\
\text { material } \\
\text { - The display of the } \\
\text { AR application } \\
\text { on the } \\
\text { smartphone can't } \\
\text { directly scan the } \\
\text { marker so it takes } \\
\text { time to display } \\
\text { the solid figure. } \\
\text { - Teachers have } \\
\text { difficulty dealing } \\
\text { with students } \\
\text { were less active }\end{array}$ \\
\hline
\end{tabular}

\begin{tabular}{|c|c|}
\hline Data reduction & Conclusion \\
\hline $\begin{array}{l}\text { to determine the } \\
\text { elements of a } \\
\text { polyhedron, students } \\
\text { only mention the } \\
\text { elements seen in the } \\
\text { media, but elements } \\
\text { such as face diagonal, } \\
\text { space diagonal and } \\
\text { diagonal planes are not } \\
\text { mentioned. } \\
\text { - When the teacher asks } \\
\text { students to rotate the } \\
\text { polyhedron to see the } \\
\text { overall shape of the } \\
\text { shape, the image rotates } \\
\text { rapidly so that students } \\
\text { are confused when they } \\
\text { want to see the back of } \\
\text { the shape. } \\
\text { - Lack of time required } \\
\text { by the teacher for } \\
\text { students to understand } \\
\text { the material } \\
\text { polyhedron of } \\
\text { - The abilities of students } \\
\text { are different so there are } \\
\text { students who } \\
\text { immediately understand } \\
\text { the material and there } \\
\text { are students who are } \\
\text { still slow } \\
\text { understanding } \\
\text { material }\end{array}$ & $\begin{array}{l}\text { in exploring solid } \\
\text { figure in media so } \\
\text { when teacher } \\
\text { asked to describe } \\
\text { the net of } \\
\text { polyhedron some } \\
\text { students only } \\
\text { described the } \\
\text { same shapes as } \\
\text { those shown on } \\
\text { AR media } \\
\text { - Navigation in } \\
\text { applications is } \\
\text { too sensitive } \\
\text { makes students } \\
\text { confused when } \\
\text { rotating shapes }\end{array}$ \\
\hline
\end{tabular}

In addition, there are also challenges faced by students in learning geometry using AR learning media. The data is presented in Table 10.

Table 10. Students' challenges in learning geometry with AR learning media

\begin{tabular}{|c|c|}
\hline Data reduction & Conclusion \\
\hline $\begin{array}{l}\text { - The nets of solid } \\
\text { figure displayed on } \\
\text { the media are only } 1 \\
\text { shape so that students } \\
\text { are still confused } \\
\text { when asked to } \\
\text { describe the nets of } \\
\text { solid figure with } \\
\text { another nets }\end{array}$ & $\begin{array}{l}\text { The use of media } \\
\text { that is still not } \\
\text { maximized resulted } \\
\text { in students not being } \\
\text { able to understand } \\
\text { the elements of solid } \\
\text { figure and the net of } \\
\text { the solid figure. }\end{array}$ \\
\hline
\end{tabular}


DOI: https://doi.org/10.24127/ajpm.v10i4.3889

\begin{tabular}{l}
\hline Data reduction \\
\hline - Some teachers use \\
AR learning media \\
for 1x meeting only \\
so that students can't \\
understand the \\
difference between \\
prism and pyramid
\end{tabular}

Geometry is a material that studies points, lines and planes. According to Nur'aini et al. (2017) when compared to other fields in mathematics, geometry is one of the fields in mathematics that is considered the most difficult to understand. The challenge faced by teachers in teaching geometry to students is the lack of time required by the teacher to pay attention to students in understanding the material. In addition, the learning media are limited so that students cannot interact directly with these props. Therefore, we need learning media that can interact directly with students. But, the challenge faced by teachers using AR learning media is the lack of complete information so that teachers are still confused in using AR learning media and the camera used cannot scan markers clearly so that the teacher cannot immediately display the projections of the building space properly. The limitations of information to learn how to used media such as AR are very limited and ultimately make it difficult for teachers (Guntur, 2015). Phon et al. (2014) also stated that errors that occur in the use of AR applications cause stress to the teacher. This is also in line with Retnawati et al. (2017) stated that the most challenge of it is teachers' limited knowledge and ability of IT. On the results of interviews, teachers still rarely use AR for learning. Some teachers only use AR learning media for a maximum of $4 x$ meetings and it is carried out on certain learning indicators such as net of polyhedron.
Applications that are rarely used make them unable to reach all knowledge and implement the learning process and use technology properly (Retnawati et al., 2017).

Although the use of AR faces many challenges, there is a huge potential possessed by AR. AR can be used as an additional learning tool for students. This will enable teachers and students to be accustomed to using technology and allow more research to be developed (Thornton et al., 2012). When the teacher implements AR learning media, students become more interested in using learning media because it is new to them. Students explore the learning media, then analyze the shape of the space in 3D. This provides new experiences to students about the sides in a shape that they usually only see in 2D. Coimbra (2015) also stated that "augmented reality can encourage motivation, comprehension and a higher involvement with the contents to be learned. Thus, it may increase the use of information and access to knowledge, improve digital and info-inclusion".

In connection with the polyhedron material, AR learning media can also provide a comprehensive experience from concrete to abstract things. Research from Suharso (2012) stated that $85 \%$ of teachers thought that with the application of 3D shapes, it could improve students' understanding of the 3D sub-material mathematical material. If you look closely, most of the material in mathematics learning can be presented in various forms such as pictures, tables, diagrams and certain patterns, the forms of presenting the material are closely related to students' spatial reasoning. In the learning process, students are assisted when they imagine the nets of solid figure. 
Students try to rotate the solid figure to analyze the net.This finding is also in line with (Mustaqim, 2016) which implies a similar thing.

Based on the data, when the teachers asked students to redraw the net in other form than the example provided by the learning media, there are several students who describe the net of solid figure by drawing a rectangle on the perpendicular side of the prism. This states that AR learning media still helps students understand the material of solid figure that needs to display its visualization. AR display also helps students to develop spatial visualization skills, namely the ability to imagine changes in shape or changes in the place of a shape. In addition, 3D views enable students to see changes in the shape of objects from various perceptions or spatial perception abilities. Thus, AR-based media can cover the weaknesses of using a blackboard to draw solid figure (Pangestu \& Setyaningrum, 2020).

On the other hand, there are challenges faced by teachers in teaching geometry with AR learning media. One of them is the different abilities of students. Based on the data obtained, several teachers used the media for one meeting on the indicator of solid figure's net because students still have difficulty imagining the shape of the nets. When the teacher asked students to draw the net set of figures other than the ones provided in AR media, there were students who still have difficulty in drawing the nets of solid figure. There were students who redrawn the net of triangular prism by drawing the isosceles trapezoid shape on its vertical side, but they mention different shape in their explanation. In addition, there are students who describe the shape of the net of triangular prism shapes just like the pictures in the media. Therefore, the teacher needs to give more time to students to understand the material using the AR learning media.

\section{CONCLUSIONS}

The presence of Augmented Reality learning media is something new for teachers in delivering material. This also provides added value in learning activities so that teachers do not only use conventional media but they can use media that makes students interact more directly. The large number of uses of AR learning media is a challenge that needs to be paid attention by the teachers. Teachers' challenges in teaching geometry using augmented reality learning media are the teachers still had difficulty in monitoring students whether they correctly understood the material or not during learning process in the online classes because some students didn't have smartphones that support the learning process, the limited time that the teachers had to explain the material, the display of the AR application on the smartphone can't directly scan the marker so it takes time to display the solid figure, teachers have difficulty dealing with students were less active in exploring solid figure in media so when teacher asked to describe the net of polyhedron some students only described the same shapes as those shown on AR media, and navigation in applications is too sensitive makes students confused when rotating shapes.

The challenges that arise in this research become a potential for other researchers to develop AR in other materials. In addition, training is needed for teachers to use AR in learning mathematics as an effort to develop technology and become one of the interactive media for students. 
DOI: https://doi.org/10.24127/ajpm.v10i4.3889

\section{REFERENCE}

Abas, H., \& Badioze Zaman, H. (2010). Reka bentuk dan Pembangunan Penceritaan Digital dan Teknologi Realiti Tambahan ( Augmented Reality ) untuk Membantu Pelajar Pemulihan Membaca Bahasa Melayu. Proceedings of Regional Conference on Knowledge Integration in ICT 2010 161, (2001), 161-170.

https://doi.org/10.1039/c4nr03210a

Adam, S., \& T.S, M. (2015). Pemanfaatan Media Pembelajaran Berbasis Teknologi Informasi Bagi Siswa Kelas X Sma Ananda Batam. CBIS Journal, 3 No 2(ISSN 2337-8794), 78-90.

Agrawal, K., Kulkarni, M., A.Josh, S., \& Tiku, N. (2015). Augmented reality. International Journal of Advance Research Computer Sience and Management Studies., 2(3), 114-122.

Arsyad, A. (2016). Media Pembelajaran. Jakarta: Raja Grafindo Persada.

Awwalin, A. A. (2021). Analisis kesulitan siswa SMP kelas VIII pada materi bangun ruang sisi datar. Jurnal Pembelajaran Matematika Inovatif, 4(1), 225-230. https://doi.org/10.22460/jpmi.v4i1.22 5-230

Coimbra, M. T., Cardoso, T., \& Mateus, A. (2015). Augmented Reality: An Enhancer for Higher Education Students in Math's Learning? Procedia Computer Science, 67(Dsai), 332-339. https://doi.org/10.1016/j.procs.2015.0 9.277

Gagne, R. M., Briggs, L. J., \& Wager, W. W. (2020). Principles of Instructional Design. In Ted Buchholz. https://doi.org/10.1525/97805203413 02-010

Guntur, M. I. S. (2015). Persepsi guru matematika sma di kayuagung terhadap kurikulum 2013. Jurnal Pendidikan Matematika, 9(1), 68-77. https://doi.org/10.22342/jpm.9.1.213 $4.68-77$
Hadijah, S. (2018). Analisis Respon Siswa dan Guru Terhadap Penggunaan Multimedia Interaktif dalam Proses Pembelajaran Matematika. Jurnal Numeracy, $\quad 10(2), \quad 1-15$. https://doi.org/https://doi.org/10.4624 4/numeracy.v5i2.391

Lee, K. (2012). Augmented Reality in Education and Training, , 56(2), 1321. doi: Tech Trends, 56(2), 13-21. https://doi.org/10.1007/s11528-0120559-3

Mustaqim, I. (2016). Pemanfaatan Augmented Reality Sebagai Media Pembelajaran. Jurnal Pendidikan Teknologi Dan Kejuruan, 13(2), 174. https://doi.org/10.1109/SIBIRCON.2 010.5555154

NCTM. (2000). The principles and standards for school mathematics. Reston: National Council of Teachers of Mathematics.

Nugraha, A., \& Muhtadi, A. (2015). Pengembangan Multimedia Pembelajaran Matematika Pada Materi Bangun Ruang Sisi Datar untuk Siswa SMP kelas VIII. Jurnal Inovasi Teknologi Pendidikan, 2(2), 157-168. Retrieved from http://journal.uny.ac.id/index.php/jitp \%OAPENGEMBANGAN

Nur'aini, I. L., Harahap, E., Badruzzaman, F. H., \& Darmawan, D. (2017). Pembelajaran Matematika Geometri Secara Realistis Dengan GeoGebra. Matematika, 16(2), 1-6. https://doi.org/10.29313/jmtm.v16i2. 3900

Pangestu, A., \& Setyaningrum, W. (2020). Instructional media for space geometry based on augmented reality to improve students' spatial reasoning. Journal of Physics: Conference Series, 1581(1), 0-6. https://doi.org/10.1088/17426596/1581/1/012058

Phon, D. N. E., Ali, M. B., \& Halim, N. D. A. (2014). Collaborative Augmented Reality in Education: A Review. 2014 International Conference on Teaching and Learning in Computing and Engineering, 78-83. 
DOI: https://doi.org/10.24127/ajpm.v10i4.3889

Purborini, S. D., \& Hastari, R. C. (2019). Analisis Kemampuan Spasial Pada Bangun Ruang Sisi Datar Ditinjau Dari Perbedaan Gender. Jurnal Derivat: Jurnal Matematika Dan Pendidikan Matematika, 5(1), 49-58. https://doi.org/10.31316/j.derivat.v5i 1.147

Rabbi, I., \& Ullah, S. (2013). A Survey on Augmented Reality Challenges and Tracking. Journal for Printing Science and Graphic Communications, 24(1-2), 29-46.

Retnawati, H., Munadi, S., Arlinwibowo, J., Wulandari, N. F., \& Sulistyaningsih, E. (2017). Teachers' difficulties in implementing thematic teaching and learning in elementary schools. New Educational Review, 48(2), 201-212. https://doi.org/10.15804/tner.2017.48 .2 .16

Siswanto, R. D. (2016). Asosiasi Antara Kemampuan Geometri Spasial Dengan Kemampuan Berpikir Kreatif Matematis Siswa. KALAMATIKA Jurnal Pendidikan Matematika, 1(2), 141.

https://doi.org/10.22236/kalamatika.v ollno2.2016pp141-146

Suharso, A. (2012). Model Pembelajaran Interaktif Bangun Ruang 3D berbasis Augmented Reality. Majalah Ilmiah Solusi Ursika., 11(24), 1-11.

Syahputra, E. (2013). Peningkatan Kemampuan Spasial Siswa Melalui Penerapan Pembelajaran Matematika Realistik. Jurnal Cakrawala Pendidikan, 3(3), 353-364. https://doi.org/10.21831/cp.v3i3.162 4

Syahputra, E. (2018). PEMBELAJARAN ABAD 21 DAN PENERAPANNYA DI INDONESIA. Seminar Nasional SAINS, TEKNOLOGI, HUMANIORA DAN PENDIDIKAN 2018 Universitas Quality, I(November), 1276-1283.

Zuin, M., Rigatelli, G., Faggian, G., \& Roncon, L. (2018, August). Mathematics and thrombolysis: Role of the mathematical modelling in understanding and developing blood clot fragmentation. European Journal of Internal Medicine, Vol. 54, pp. e19-e20. https://doi.org/10.1016/j.ejim.2018.0 6.003 